\title{
The Link Between Car Sales and the Economic Crisis in the European Union at the Time of the Covid-19 Epidemic
}

\author{
Submitted 05/09/20, 1 st revision 01/10/20, 2nd revision 09/1 1/20, accepted 15/12/20
}

\section{László Török ${ }^{1}$}

\begin{abstract}
:
Purpose: Car production is one of the most important bases of the European Union's economy. The study examines the negative effects of the Covid-19 epidemic on the new car market in the European Union in the first half of 2020.

Design/Approach/Methodology: First, the economic and emotional elements of buying new cars are presented to consumers. The methodological part presents the data on new cars sold and the decrease in GDP during the period under review. It then examines, using a correlation calculation, how strong the relationship is between GDP as a dependent variable and new car sales as an independent variable.

Findings: The analysis confirms the hypothesis that the Union economy is highly dependent on emissions from the automotive industry. Using data collected for research, the study also confirms that the outbreak caused panic in the new car market. The dissertation sees this as evidenced by the fact that the median value calculated from the decrease in new car sales per member state is more than three times higher than the value of GDP decline in the member states.

Practical Implications: The experience of previous crises demonstrates that these crises have the potential to fundamentally change consumer behavior and that these changes persist in consumers. This is likely to be the case after the Covid-19 epidemic. Those working in the automotive sector need to be prepared for these changes.

Originality/Value: Due to the high economic weight of the Union's car industry, it is impossible to reach the pre-crisis level of EU GDP without rehabilitating the sector.
\end{abstract}

Keywords: Covid-19, European Union, GDP, car sales.

JEL codes: D01, E23, E32.

Paper Type: Research Article.

ISSN: 2241-4754, H index 10, Q3.

Note: Project no. TKP2020-NKA-04 has been implemented with the support provided from the National Research, Development and Innovation Fund of Hungary, financed under the 2020-4.1.1-TKP2020 funding scheme.

${ }^{1}$ Ph.D., University Instructor, University of Debrecen, Faculty of Engineering, Department of Engineering Management and Enterprise, Qualified Lecturer, Chamber of Hungarian Auditors, Hungary, e-mail: dr.torok.laszlo@eng.unideb.hu; 


\section{Introduction}

The automotive industry is one of the most important bases of the European Union's economy. According to preliminary estimates, car production and sales in the European Union will suffer the greatest losses after the tourism and entertainment sectors as a result of the coronavirus epidemic. The high share of car production in GDP justifies a focus on business cycle research on the extent of the sector in the first half of 2020 (the period in which the pandemic began and unfolded), based on the statistics available so far. downturn. The very reduced figures for car sales alone also say a lot about the situation in the sector.

The study seeks to answer the question of how car sales data related to the decline in GDP measured over the same period. To demonstrate this, the study examines the relationship between the two variables using a correlation calculation. The hypothesis is that there is a link between GDP and the decline in car sales, but the calculations will also show how close the relationship between the two variables is in the member states of the European Union.

\section{Data and Methodology}

Buying a car is of paramount importance among consumer decisions. Its importance is given by the fact that the purchase of a car after the purchase of a home is the second-largest amount of expenditure in the line of consumer expenditure. Modeling consumer behavior has always been at the forefront of microeconomic research. Internal (psychological) and external (contextual) determinants must also be taken into account in the modeling. However, some integrative models try to consider both at the same time, even though its operational implementation is not straightforward (Jackson, 2005).

However, some basic consumer behaviors need to be considered in modeling. One of the most important axioms of neoclassical economics is that the willpower of consumers is unlimited. They are thus able to carry out their economic transactions without wavering Jolls et al. (1998). In neoclassical economics, the consumer is fully informed, sovereign, and makes his decision in a static problem space in which time has no role (Rabin, 2002). Olander and Thogersen (1995) propose an integrative model that takes into account both the internal and external types of consumer factors.

This analytical framework has been called the Motivations-Opportunities-Abilities (MOA) model. This model can be used well in understanding complex consumer behavior (Parkinson et al., 2016). It can be applied when it is assumed that the consumer is acting because he or she has the motivation to do so and has the skills and opportunities to act as a consumer. The MOA model has been used in several studies (Gruen et al., 2007) used it as a framework to study the behavior of online 
exchange. This model was also used in their study by (Hung and Petrick, 2012) to explain consumer intentions.

The car brand has become a status symbol in consumer societies. The car is a fashion and utility product that is good for the market because it keeps consumer demand for cars high. Car buying and car use are motivated by symbolic and emotional (hedonic) factors. This has been demonstrated in several studies, such as (Belgiumwan et al., 2016; Ory and Mokhtarian, 2005). The car thus also has a symbolic function with which the buyer expresses his self-image. A self-owned car facilitates social interaction and social acceptance among consumers and allows the expression of core values related to the consumer (Kringelbach and Berridge, 2017). Relevant empirical experience is that crises have the potential to fundamentally change consumer behavior and that these changes are persistent (McPartlin, 2010).

The coronavirus epidemic broke out in March 2020, but its negative economic effects began to unfold in the second quarter of the year and then unfold thereafter. The situation and trends in the sector during this period are well illustrated by the (ACEA, 2020) report. According to this, the European automotive sector directly or indirectly employs 13.8 million people, $6.1 \%$ of those employed in the European Union. 11.4 percent of manufacturing jobs, 3.5 million, are in the automotive sector.

ACEA forecasts that the number of cars sold in the European Union could fall from 12.8 million in 2019 by more than 3 million, or 25 percent, to 9.6 million this year. In its latest January forecast, ACEA forecasts another 2 percent decline for the current year. Due to the disease control measures introduced in mid-March, sales decreased by 38.9 percent from the beginning of the year to the end of June compared to 2019. However, thanks to the phasing out of restrictive measures, the situation will ease for the rest of the year, according to ACEA's forecast. Car sales are set to be the lowest this year since 2013 when automotive sales hit the deepest point following the 2008-2009 financial crisis. The percentage decline, on the other hand, will be the largest the European automotive industry has ever suffered.

As a result of the virus epidemic, car factories shut down and production was suspended for a longer or shorter period, resulting in a significant reduction in emissions on the supply side. At the same time, the demand for cars has also declined. In economic uncertainty, the purchase of high-value investment assets or consumer goods (such as cars), which can be postponed for a longer or shorter period, is also delayed by institutional/corporate buyers and individuals. Longer or shorter shutdowns of Chinese industrial suppliers and stagnation of business processes due to travel restrictions alone have led to a decline in production. In production organized based on modern processes and based on minimum inventory, the interruption of the supply chain was accompanied by an immediate decrease in capacity (Ivanov and Dolgui, 2020). This statement is also true for other industries.

In a pandemic situation, the demand for basic products is increasing; on the other hand, the supply of raw materials is significantly reduced by limiting production 
capacity. These double disturbances suddenly affect the production process and the process can collapse without immediate and necessary steps. Quarantine measures mean that people do not visit car dealerships, travel less, cars are less used, and their replacement can, therefore, be delayed. Together, they result in a 21 to 54 percent drop in car sales in some EU countries.

The real economic crisis caused by the coronavirus is accompanied by a decline in GDP. However, the magnitude of the decline varies significantly between the Member States. Differences cannot be linked to a country's size, level of development, or whether that country is a member of the euro area. It can be said that certain country specifics result in a larger decline. Examples are the high share of exports in GDP or the high weight of credit-financed sectors in a given country. In Germany, for example, GDP is expected to decline 6.3 percent this year with a budget deficit of 7.25 percent (Reuters, 2020). These high negative macroeconomic values are closely related to Germany's high export exposure. In Hungary and Slovakia, the automotive industry plays a key role in GDP, so these countries will also be strongly weighed down by the real economic crisis. This structural feature may, therefore, result in a larger decline in GDP in countries with significant automotive industries (Sturgeon and Biesebroeck, 2009).

It is generally true that a decline in GDP and a significant, sometimes dramatic, rise in unemployment can easily trigger social tensions and lead to political unrest (Ochsen and Welsch, 2006). This indicator has risen to very high levels, especially in Spain and Greece. In those EU countries where they were able to build up significant reserves in the boom years before the crisis, they can now provide more support to mitigate the effects of the crisis. Some of these grants are social and others create resources for companies.

Many examples of this could be listed, as shown by (Andoh, 2020). It is a fact of economic history that every crisis can also be an effective period of restructuring of a given national economy, an effective period of economic renewal. It is then necessary for public subsidies to play a significant role in corporate investment to support technological change. One such sector today is the car industry, where some Member States are specifically encouraging energy-saving and climate-friendly developments. Globally, priority will also be given to automotive factories for the development and production of electric cars (Lutsey et al., 2018). But it is also not uncommon for temporary tax breaks to take place in general to improve the liquidity of companies.

Some form of job retention support exists in almost all Member States. A significant impact can be expected most where not only adequate resources are available, but also good institutional conditions are in place to achieve this goal. Examples of job retention subsidies are found in almost all EU Member States (Bennedsen et al., 2020). 
The coronavirus epidemic will significantly increase the gross consolidated public debt of the member states of the Union. Two factors will have a strong impact on rising government debt ratios. On the one hand, due to the decline in GDP, national budgets receive less tax and contribution revenue from taxpayers. On the other hand, companies and households need to be supported, but these subsidies will increase national budget spending. This, in turn, will increase government deficits. The cumulative deficit of general government deficits from previous years and decades is nothing but the gross public debt of a country. Even though the epidemic did not appear in Europe until March, the gross public debt of the member states started to increase already in the first quarter of 2020.

According to data provided by the EU's statistical office, the government debt-toGDP ratio rose to 86.3 percent in the euro area from 84.1 percent in the last quarter of last year and from 77.7 percent to 79.5 percent in the EU as a whole. In the first quarter of this year, Estonia had the lowest government debt at 8.9 percent of GDP, followed by Bulgaria (20.3 percent) and Luxembourg (22.3 percent). The highest government debt-to-GDP ratio was in Greece in the first quarter of this year, with 176.7 percent, followed by Italy with 137.6 percent, Portugal with 120 percent, Belgium with 104.4 percent, and France with 101.2 percent.

Compared to the last quarter of last year, the debt-to-GDP ratio of 24 countries increased and that of three decreased. Belgium's government debt-to-GDP ratio increased the most, by 5.7 percentage points, followed by Finland $(+4.9$ percentage points), Slovenia ( +3.5 percentage points), Spain $(+3.4$ percentage points $)$, and France (+3.1 percentage points). Lithuania's government debt-to-GDP ratio decreased the most, by 3 percentage points, compared to the last quarter of last year (Eurostat, 2020a).

Macroeconomically, member states would have the opportunity to prevent an increase in their gross public debt. To this end, they could privatize certain state property. They could sell public assets, but the most common method would be to sell public companies to private investors.

There are currently several obstacles to this. The first is that the sale of state property usually encounters resistance from members of society because citizens in such a case feel that the state is selling property that is partly their property.

Second, it should be seen that in times of crisis, assets/shares depreciate, with investors only paying a significantly lower price for state-owned property relative to fair market value.

The third argument against privatization is that, except for a few Member States (such as Greece), the state assets that can still be sold are relatively low in the Member States of the Union. Despite all this, there are attempts and actions in the global economy to sell state-owned properties/companies to investors and to reduce public debt from revenues (Török, 2019). 


\section{Results}

The results of the research are illustrated in the following figures. The data in Figure 1 allow for extensive economic analysis. The first striking correlation with the figure is that the decline in GDP is significant in all member states, but the decline in new car sales is much more dynamic than this. This is reflected in the empirical observation that when workers 'jobs become precarious, the first thing they give up is not to buy a new car. In times of crisis, similar reactions can be seen on the part of companies, because companies are also postponing their car purchases due to the uncertain future. If we add to this the fact that a significant proportion of new cars are bought on credit, it becomes clear why the crisis in April 2020 hit the car industry the hardest hit the car industry.

Figure 1. Decrease in GDP and car sales of the European Union member states compared to the 2nd quarter of the previous year, as a percentage.

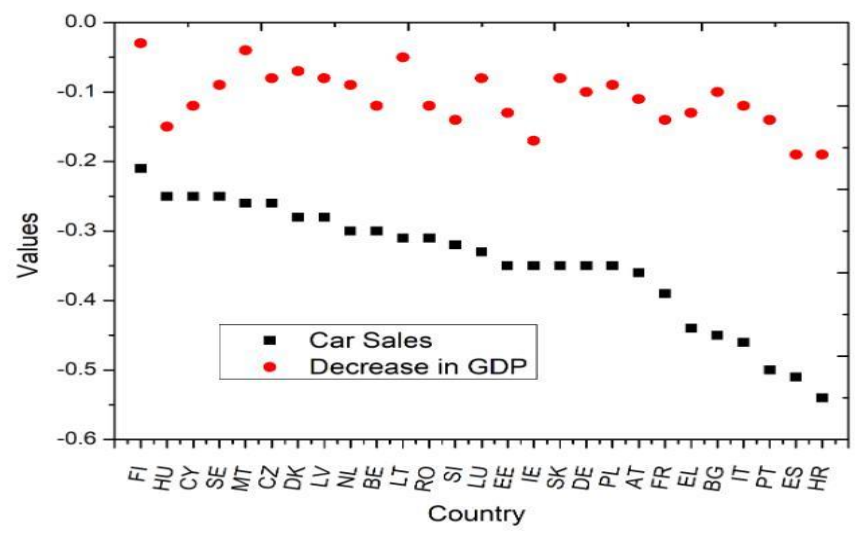

Source: Eurostat, 2020b, ACEA, 2020, own editing.

In times of crisis, the reaction of car buyers depends not only on the past, at least as much, or even more on their expectations for the future. The crisis is increasing the number of people and companies who are unable to buy and replace cars, and it is also deterring the insecurity, the populous camp that is postponing their demand. As the risk of an epidemic decrease, the economic and employment situation will also stabilize, and if workers find that their jobs are no longer in danger, they are likely to start buying cars again. Companies will respond similarly because as the pressure of the crisis eases, the future will become more predictable, and businesses will increase their purchases of new cars. Production volumes have already increased in June, driven by the reopening of plants and growing demand, but analysts say demand will not return to pre-coronavirus levels again in five years.

The relationship between GDP and car sales can be interpreted as a stochastic relationship, where variables can be assumed to be linear. The independent variable, in this case, is the number of purchases of new cars, and the dependent variable is 
the decline in GDP. With the data revealed during the research, I examined the closeness of the relationship between the economic downturn and car sales. Pearson's correlation coefficient is 0.64117 . This value presents that there is a stronger-than-average relationship between declining GDP and declining car purchases but by no means a functional contact between the individual variables.

The value of the coefficient shows that the crisis caused by Covid-19 in the member states of the European Union is causing a recession, as a result of which new car sales have fallen drastically, exceeding the decline in GDP. If the decline in new car sales were equivalent to the decline in GDP, at the same rate, the relationship between the two variables would be functional. This condition would be reflected in the values of the independent variable (car sales) and the dependent variable (change in GDP) being the same. The value of the correlation coefficient measured between the two variables also highlights that the weight of the automotive industry in the European Union is very significant.

Figure 2. Correlation between GDP decline and car sales decline.

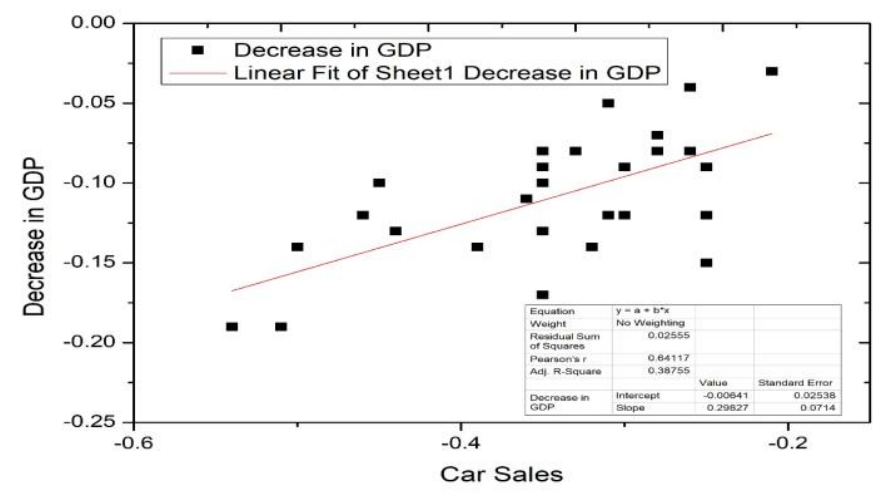

Source: Eurostat, 2020b, ACEA, 2020, own editing.

Figure 3. The decline in new car sales "overreacts" to the decline in GDP

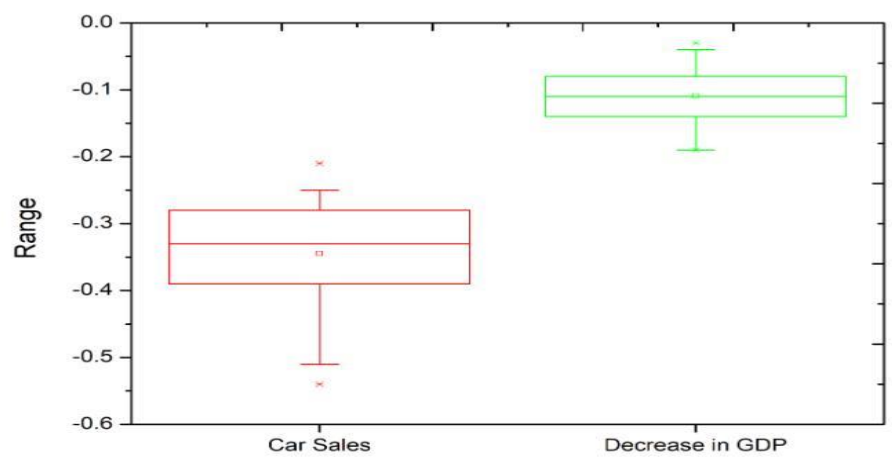

Source: Own editing. 
Based on the box chart analysis I examined the following: mean, standard deviation lower $95 \% \mathrm{Cl}$ of mean, upper $95 \% \mathrm{Cl}$ of mean, sum, minimum, median, maximum, 1st quartile, 3rd quartile.

The figure clearly shows that while the median value of GDP declines is close to 11 percent, the decline in sales is around 36 percent. The decline in new car sales "overreacts" to the decline in actual economic emissions. This is thus confirmed by the boxing chart of the two variables shown in Figure 3. The figure confirms the relationship formulated above. From this, it seems clear that the significant decline in new car purchases is a market overreaction, as the decline in new car sales is on average more than three times the average GDP decline in the European Union. From this, a kind of panic reaction on the part of car buyers can be identified.

However, in a crisis, as economic history has repeatedly shown, panics cause really big losses. / The fact that purchases were physically impossible also contributed to the large-scale decline in car sales by temporarily closing car showrooms. The austerity measures taken to curb the Covid-19 coronavirus, the epidemic, wreaked havoc on the European car market: just over 270,000 new cars were placed on the market in April alone, a historic drop of 76.3 percent from April 2019. We have seen dramatic declines in the dominant car markets/.

\section{Conclusions}

In the European Union economy, car manufacturing is one of the sectors with the largest output. The Union's car industry / and the global car industry / will never be the same again as before the outbreak. The COVID-19 epidemic brought the performance of the sector to an almost low point, and as a result, the macroeconomic study of this sector became a relevant research topic.

The study pointed out that buying cars among consumers is the result of complex and complex consumer behavior that is influenced by both economic and emotional elements. The experience of previous crises demonstrates that these crises have the potential to fundamentally change consumer behavior and that these changes are lasting. This is likely to be the case after the Covid-19 epidemic. Those working in the sector need to be prepared for these changes. Predicting the exact direction of change in car sales is a difficult task. Online car sales will likely gain more and more ground. This, in turn, will translate into direct purchases, so importers and car showrooms will be left out of the supply chain. Automakers will be able to gain a competitive advantage who will be able to well assess changes in consumer needs and adapt to these changes effectively.

The Covid-19 epidemic reduced new car sales in the European Union member states by an average of 36 percent and its GDP by an average of 11 percent during the period under review. The result of the correlation calculation presented in the study showed that there is a stronger than average relationship between the two variables. 
The value of Pearson's correlation coefficient confirms that the automotive sector in the European Union is very significant, as declining performance can severely reduce the Union's economic performance. It is also clear that the automotive industry does not have 4-5 years to regenerate because irreplaceable capacities can be lost during this time. Without restoring the pre-crisis situation of the car industry, it is inconceivable to reach the pre-epidemic level of the European Union's GDP.

The study also demonstrates that the decline in new car sales in the European Union "overreacts" to the decline in actual economic emissions. An analysis of the data used in the research revealed that the decline in new car sales is more than three times the decline in EU GDP. From this result, it can be concluded that the outbreak of the Covid-19 epidemic has caused panic in the European automotive value chain. This panic could be detected not only among manufacturers and buyers but also in the price development of car factory stocks. It is also necessary to stimulate the growth of market demand for cars with public funds. Examples of such instruments are the launch of coordinated exchange programs for all vehicle categories, and the support of national exchange programs with EU funds.

\section{References:}

ACEA, 2020. The automobile industry pocket guide 2019/2020. https://www.acea.be/uploads/publications/ACEA_Pocket_Guide_2019-2020.pdf (Accessed: 01.08.20).

Andoh, R. 2020. The Impact of COVID-19 on Global Economy: The Case of the Czech Republic. International Journal of Multidisciplinary Sciences and Advanced Technology, Volume 1, Special Issue 2 Covid-19, 22-29.

Bennedsen, M., Larsen, B., Schmutte, I., Scur D. 2020. Preserving job matches during the COVID-19 pandemic: firm-level evidence on the role of government aid. Project: COVID-19 and Labor Markets. DOI: 10.13140/RG.2.2.15337.11366.

Belgiawan, P., Schmocker, J.D., Fujii, S. 2016. Understanding car ownership motivations among Indonesian students. International Journal of Sustainable Transportation, 10(4), 295-307. https://doi.org/10.1080/15568318.2014.921846.

Eurostat. 2020a. First quarter of 2020 compared with the fourth quarter of 2019. https://ec.europa.eu/eurostat/documents/2995521/11129607/2-22072020-APEN.pdf/ab6cd4ff-ec57-d984-e85a-41a351df1ffd, (Accessed: 13.08.20).

Eurostat. 2020b. GDP and employment flash estimates for the second quarter of 2020, https://ec.europa.eu/eurostat/documents/2995521/10545332/2-14082020-APEN.pdf/7f30c3cf-b2c9-98ad-3451-17fed0230b57, (Accessed: 14.08.20).

Gruen, T., Osmonbekov, T., Czaplewski, A. 2007. Customer-to-customer exchange: Its MOA antecedents and its impact on value creation and loyalty. Journal of Academic Marketing Science, 36, 537-549. https://doi.org/10.1007/s11747-006-0012-2.

Hung, K., Petrick, J. 2012. Testing the effects of congruity, travel constraints, and selfefficacy on travel intentions: An alternative decision-making model. Tourism Management, 33, 855-867. https://doi.org/10.1016/j.tourman.2011.09.007.

Ivanov, D., Dolgui A. 2020. Viability of intertwined supply networks: extending the supply chain resilience angles towards survivability. A position paper motivated by COVID-19 outbreak. International Journal of Production Research, 58(4), 1-12. DOI: $10.1080 / 00207543.2020 .1750727$.

Jackson, T. 2005. Motivating sustainable consumption. A review of evidence on consumer 
behavior and behavioral change (A report to the Sustainable Development Research Network), Centre for Environmental Strategy, University of Surrey.

Jolls, C., Sunstein, C.R., Thaler, R. 1998. A behavioral approach to law and economics. Stanford Law Review, Vol. 50, 1471-1550. https://doi.org/10.2307/1229304.

Kringelbach, M., Berridge, K. 2017. The affective core of emotion: Linking pleasure, subjective well-being, and optimal metastability in the brain. Emotion Review July, 9(3), 191-199. https://doi.org/10.1177/1754073916684558.

Lutsey, N., Grant, M., Wappelhorst, S., Zhou, H. 2018. Power Play: How governments are spurring the electric vehicle industry. https://theicct.org/publications/global-electricvehicle-industry. (Accessed 12.08.20).

McPartlin, S., Dugal, L.F., Whitfield M.B. 2010. New Consumer Behavior Paradigm: Permanentor Fleeting? Kantal Retail-PriceWaterhouseCoopers, http://www.silvergroup.asia/uploads/page/doc/the-new-consumer-behaviorparadigm.pdf. (Accessed: 16.08.20).

Ochsen, C., Welsch, H. 2006. The Social Costs of Unemployment: Accounting for Unemployment Duration. Applied Economics, 43(60). DOI: 10.1080/00036841003761900.

Olander, F., Thogersen, J. 1995. Understanding consumer behavior as a prerequisite for environmental protection. Journal of Consumer Policy, 18, 345-385. https://doi.org/10.1007/bf01024160.

Parkinson, J., Schuster, L., Russell-Bennett, R. 2016. Insights into the complexity of behaviors: The MOAB framework. Journal of Social Marketing, 6(4), 412-427. https://doi.org/10.1108/jsocm-10-2015-0071.

Ory, D., Mokhtarian, P. 2005. When is getting there half the fun? Modeling the liking for travel. Transportation Research, Part A, 39, 97-123. https://doi.org/10.1016/j.tra.2004.09.006

Rabin, M. 2002. A perspective on psychology and economics. European Economic Review, Vol. 46, No. 4-5, 657-685. https://doi.org/10.1016/s0014-2921(01)00207-0.

Reuters. 2020. German cabinet approves record new borrowing in coronavirus fight, https://www.reuters.com/article/us-health-coronavirus-germany-politics/germancabinet-approves-record-new-borrowing-in-coronavirus-fight-idUSKBN23O1Y9. (Accessed 11.07.20).

Sturgeon, T.J., Biesebroeck, J.V. 2009. Crisis and protection in the automotive industry: a global value chain perspective. Policy Research Working Paper, 5060. https://doi.org/10.1596/1813-9450-5330.

Tradingeconomics. 2020. Estonia GDP Annual Growth Rate https://tradingeconomics.com/estonia/gdpgrowth-annual. (Accessed: 14.08.20).

Török, L. 2019. Do Changes in the Economic Role of States through Privatization matter? The Brazilian Case. International Journal of Engineering and Management Sciences, 4(4), 125-136. https://doi.org/10.21791/JJEMS.2019.4.13. 